ReVISTA de BIOLOGía TROPICAL

\title{
First record of young-of-the-year Scalloped hammerhead shark, Sphyrna lewini (Carcharhiniformes: Sphyrnidae) from Isla del Coco National Park, Costa Rica
}

\author{
Ilena Zanella ${ }^{1}$, Andrés López-Garro ${ }^{1}$, D. Michelle McComb-Kobza ${ }^{2}$, Geiner Golfín-Duarte ${ }^{3}$, \\ Maikel Pérez-Montero ${ }^{3}$ \& Josué Morales ${ }^{3}$ \\ 1. Asociación Conservacionista Misión Tiburón, Playas del Coco, Guanacaste, Costa Rica; Telefax: (506) 2697-1847; \\ izanella@misiontiburon.org, alopez@misiontiburon.org \\ 2. Ocean First Institute, 3015 Bluff Street, Boulder, Colorado 80301, USA; mikki@oceanfirstinstitute.org \\ 3. Parque Nacional Isla del Coco. Área Conservación Marina Isla del Coco. Sistema Nacional de Áreas de Conservación, \\ Costa Rica; geiner.golfin@sinac.go.cr, maikeel.perez@sinac.go.cr, josue.morales@sinac.go.cr
}

Received 23-VI-2014. Corrected 01-IX-2015. Accepted 08-IX-2015.

\begin{abstract}
The Scalloped hammerhead shark, Sphyrna lewini is a coastal and pelagic circumglobal species that resides within coastal warm temperate and tropical seas. Sphyrna lewini exhibits strong intraspecific segregation: neonates and young-of-the-year spend the first part of life in coastal inshore waters (nursery grounds), while adults migrate offshore, returning to protected nursery habitats for mating and pupping. On December 3, 2014, at approximately 19:00 hr, four young-of-the-year $S$. lewini were caught with hand line in Wafer Bay, Isla

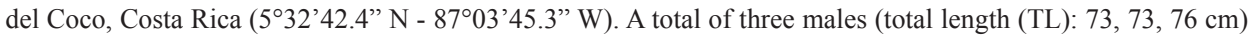
and one female (TL: $75 \mathrm{~cm}$ ) were recorded. The presence of these individuals at Isla del Coco suggests that a pregnant female gave birth in or near Wafer Bay, which may be a nursery ground for S. lewini. We recommend further study to evaluate the presence and movements of young-of-the-year and juvenile $S$. lewini in Wafer Bay to determine if this was an isolated incident or if the bay is a nursery ground for S. lewini. Rev. Biol. Trop. 64 (Suppl. 1): S201-S204. Epub 2016 February 01.
\end{abstract}

Key words: oceanic island, nursery area, shark intraspecific segregation, Sphyrna lewini.

The Scalloped hammerhead shark, Sphyrna lewini (Griffith \& Smith, 1834) is a coastal and pelagic circumglobal species that resides within coastal warm temperate and tropical seas (Bigelow, \& Schroeder, 1948; Compagno, Krupp, \& Schneider, 1995). In the Eastern Pacific, the species ranges from southern California and the Gulf of California to Panama, Ecuador, Peru and northern Chile (Compagno et al., 1995; Bustamante, 2014).

Sphyrna lewini is highly impacted by anthropogenic activities, including overfishing and as bycatch in fisheries (Miller et al., 2013). Baum et al. (2003) reported a rapid decline in large coastal and oceanic shark populations in the Northwest Atlantic, and estimated that scalloped hammerhead sharks declined by over $75 \%$ in the past 15 years. As noted recently, abundance of $S$. lewini in Isla del Coco Nationa Park, Costa Rica, has decreased by approximately $45 \%$ during the last 21 years (White, Myers, Flemming, \& Baum, 2015). In 2008 the IUCN Red List classified S. lewini as Endangered, and in 2013 it was included on the Appendix II of CITES.

Sphyrna lewini is caught by different fisheries in oceanic (longlines) and coastal waters (artisanal), as consequence of the strong spatial segregation between adults and juveniles. In fact, pups and juveniles live in nursery areas located in coastal waters of estuaries, bays and mangroves, where rich nutrient waters 
provide food and protection from predators (Clarke, 1971; Branstetter, 1987; Castro, 1993, Duncan, \& Holland, 2006). Springer (1967) defines nursery areas as "coastal areas that are geographically separated from adult feeding grounds". However, Heupel, Carlson \& Simpfendorfer (2007) propose a new definition, which "requires three criterion for an area to be identified as a nursery: (1) sharks are more commonly encountered in the area than other areas, (2) sharks have a tendency to remain or return for extended periods, and (3) the area or habitat is repeatedly used across years".

The adults migrate to open waters, returning to nursery areas for mating and pupping (Clarke, 1971; Duncan, \& Holland, 2006). Schools of females $S$. lewini are known to inhabit areas near several oceanic islands within the Eastern Tropical Pacific, such as Isla del Coco, Galápagos Islands and Malpelo (Hearn, Utreras, \& Henderson, 2010). In Isla del Coco, the schools of adults females $S$. lewini are reported from sites that host mutualistic fish cleaning stations (Sibaja-Cordero, 2008; Nalesso, 2014). On the north side of Isla del Coco is located Wafer Bay (5'32'56.33" $\mathrm{N}-87^{\circ} 03^{\prime} 44.96^{\prime \prime} \mathrm{W}$ and $5^{\circ} 32^{\prime} 47.35^{\prime \prime} \mathrm{N}$ $\left.87^{\circ} 03^{\prime} 27.48^{\prime \prime} \mathrm{W}\right)$. The bay is shallow ranging from $15-20 \mathrm{~m}$ in depth with sand channels, suspended sediments and turbid waters. The Genio River, the biggest river on the island, leads into this bay, which is the major basin of the island (Sibaja-Cordero, \& Cortés, 2010; Sibaja-Cordero, Troncoso, Benavides, \& Cortés, 2012).

In Wafer Bay, on December 3, 2014 at approximately 19:00 hr, four young-of-theyear $S$. lewini were caught with hand line and a modified size five circular hook (5'32'42.4" $\left.\mathrm{N}-87^{\circ} 03^{\prime} 45.3^{\prime \prime} \mathrm{W}\right)$, at $12 \mathrm{~m}$ deep with a sea surface temperature of $29^{\circ} \mathrm{C}$ (Fig. 1). Identification of the species was attained by analysis of the following distinctive characters outlined by Compagno et al. (1995) and Compagno, Dando \& Fowler (2005): 1-a indentation located in the center of the margin of the head and two lateral slits respect to the principal; 2- the dorsal surface and flanks are gray-brown and the tips of the pectoral fins are dark, almost black; 3- the second dorsal fin is elongated almost until the beginning of the precaudal peduncle.

A total of three males (total length (TL): $73,73,76 \mathrm{~cm}$ ) and one female (TL: $75 \mathrm{~cm}$ ) were caught. The variation of size versus age of several populations of $S$. lewini has been documented. In Michoacán, Mexico, it was estimated that near term embryos are $44-50 \mathrm{~cm}$ TL (Anislado, 2000). For males, size from birth to year one is 48-74 cm TL and females $52-63 \mathrm{~cm}$ TL (Anislado, Gallardo, Amezcua, \& Mendoza, 2008; Kotas, Mastrochirico, \& Petrere, 2011). This is similar to the mean ( $74.3 \pm 17.4 \mathrm{~cm}$ TL) of 315 hammerhead juveniles analyzed within Golfo Dulce, in the South Pacific of Costa Rica (Zanella, \& López-Garro, 2015). Zarate (2010) reported age and growth of S. lewini in Oaxaca, Mexico, and estimated the first year of growth in females $(34.8 \mathrm{~cm})$ and males $(33.1 \mathrm{~cm})$.

Based on previous studies, we conclude that the $S$. lewini captured in Wafer Bay most likely have not completed the first year of life. The presence of these individuals at Isla del Coco suggests that a pregnant female gave birth at Wafer Bay, which may be used as a nursery ground for $S$. lewini. This is the first record of young-of-year hammerhead sharks from Isla del Coco National Park (Bussing, \& López, 2005; Garrison, 2005; Sibaja-Cordero,

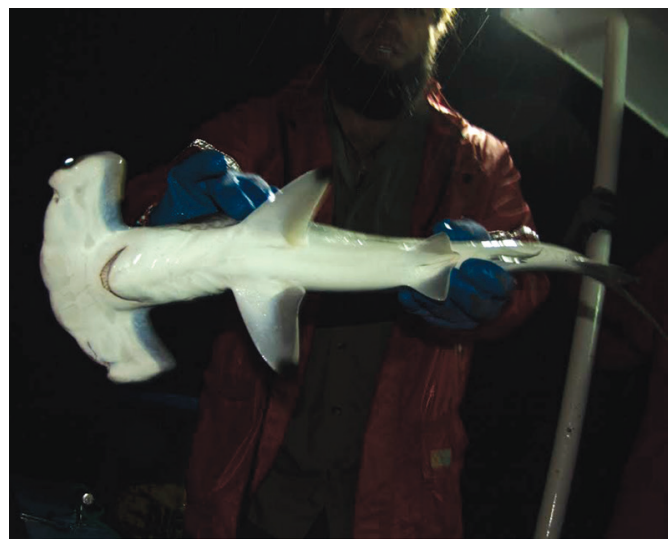

Fig. 1. Young-of-the-year scalloped hammerhead shark caught in Wafer Bay, Isla del Coco National Park. 2014. 
2008; Zanella, López-Garro, Golfín-Duarte, \& Saenz, 2012; Nalesso, 2014).

Although this report is not consistent with the traditional concept of nursery areas, because Wafer Bay is not located in coastal waters, the estuarine ecosystem offered by the Genio River could be used as nursery ground for pups and juveniles of S. lewini. In conclusion, we recommend further study to evaluate the presence of young-of-the-year S. lewini in Wafer Bay to clarify if this was an unusual event or if the bay is a nursery ground for the species.

\section{ACKNOWLEDGMENTS}

We thank the personnel of Isla del Coco National Park and Isla del Coco Marine Conservation Area for their assistance. We also acknowledge the Fundación Amigos de la Isla del Coco for supporting the expeditions.

\section{RESUMEN}

El tiburón martillo, Sphyrna lewini, es una especie costera y pelágica semioceánica, que reside en aguas tropicales y subtropicales. Presenta una fuerte segregación intraespecífica: neonatos y jóvenes viven en aguas costeras protegidas (áreas de crianza), mientras que los adultos migran aguas afuera, y vuelven a las aguas costeras y protegidas para fines reproductivos. El 3 de diciembre 2014, alrededor de las 19:00hr horas cuatro jóvenes (de un año o menos) de $S$. lewini fueron capturados con una cuerda de mano, utilizando un anzuelo circular 5 modificado, en Bahía Wafer, Isla del Coco (5³2’42.4” N - 8703'45.3" W). Fueron registrados un total de 3 machos (longitud total $73,73,76 \mathrm{~cm})$ y una hembra $(75 \mathrm{~cm})$. La presencia de $10 \mathrm{~s}$ individuos en la Isla del Coco sugiere que una hembra grávida parió en Bahía Wafer, y que posiblemente esté siendo utilizada por $S$. lewini como área de crianza. Recomendamos evaluar la presencia y los movimientos de los jóvenes de $S$. lewini en Bahía Wafer para conocer si fue un evento aislado o si realmente es un área de cría.

Palabras claves: isla oceánica, área de crianza, segregación intraespecífica, tiburones, Sphyrna lewini.

\section{REFERENCES}

Anislado, V. (2000). Ecología pesquera del tiburón martillo, en el litoral del estado de Michoacán, México. (Tesis de maestría), Universidad Nacional Autónoma de México, México DF.
Anislado, V., Gallardo, M., Amezcua, F., \& Mendoza, C. (2008). Age and growth of the scalloped hammerhead shark, Sphyrna lewini (Griffith \& Smith, 1834) from the Southern coast of Sinaloa, México. Hidrobiológica, 18(1), 31-40.

Baum, J. K., Myers, R., Kehler, D., Worm, B., Harley, S., \& Doherty, P. 2003. Collapse and conservation of shark populations in the Northwest Atlantic. Science, 299, 389-392.

Bigelow, H., \& Schroeder, W. (1948). Sharks. In J. TreeVan, C. Breder, S. Hildebrand, A. Parr, \& W. Schroeder (Eds.), Fishes of the Western North Atlantic. Part 1 (pp. 59-546). New Haven, CT., USA: Memoirs of the Sears Foundation for Marine Research, Yale University.

Branstetter, S. (1987). Age, growth and reproductive biology of the silky shark, Carcharhinus falciformis, and the scalloped hammerhead, Sphyrna lewini, from the northwestern Gulf of Mexico. Environmental Biology of Fishes, 19(3), 161-173.

Bussing, W. A., \& Lopez, M. I. (2005). Fishes of Cocos Island and Reef Fishes of the Pacific Coast of Lower Central. Revista Biología Tropical, 53(Supplement 2), 1-192.

Bustamante, C. (2014). Biology, taxonomy and distribution of south-east Pacific cartilaginous fishes. (Ph.D. thesis). University of Queensland, Queensland, Australia.

Castro, J. I. (1993). The nursery of Bull Bay, South Carolina, with a review of the shark nurseries of the southeastern coast of the United States. Environmental Biology of Fishes, 38, 37-48.

Clarke, T. A. (1971). The ecology of the scalloped hammerhead shark, Sphyrna lewini, in Hawaii. Pacific Science, 25, 133-144.

Compagno, L., Krupp, F., \& Schneider, W. (1995). Tiburones. In W. Fischer, F. Krupp, W. Schneider, C. Sommer, K. Carpenter \& V. Niem (Eds.), Pacífico centro-oriental. Volumen II. Vertebrados- Parte I. Guía FAO para la identificación de especies para los fines de la pesca (pp. 647-743). Roma, Italia: FAO.

Compagno, L., Dando, M., \& Fowler, S. (2005). Sharks of the World. Princeton, New Jersey, USA: , Princeton University Press.

Duncan, K. M., \& Holland, K. N. (2006). Habitat use, growth rates and dispersal patterns of juvenile scalloped hammerhead sharks Sphyrna lewini in a nursery habitat. Marine Ecology Progress Series, 312, 211-221.

Garrison, G. (2005). Fish of Isla del Coco/Peces de la Isla del Coco. Santo Domingo, Heredia, Costa Rica: Editorial INBio.

Hearn, A., Utreras, E., \& Henderson, S. (Eds.). (2010). Informe sobre el estado de los tiburones del 
Pacifico Este Tropical. Quito, Ecuador: Conservación Internacional.

Heupel, M., Carlson, J., \& Simpfendorfer, C. (2007). Shark nursery areas: concepts, definition, characterization and assumptions. Marine Ecology Progress Series, 337, 287-297.

Kotas, J. E., Mastrochirico, V., \& Petrere Jr., M. (2011). Age and growth of the Scalloped Hammerhead shark, Sphyrna lewini (Griffith and Smith, 1834), from the southern Brazilian coast. Brazilian Journal of Biology, 71(3), 1-7.

Miller, M., Carlson, J., Cooper, P., Kobayashi, D., Nammack, M., \& Wilson, J. (2013). Status review report: Scalloped hammerhead Shark (Sphyrna lewini). (Report to National Marine Fisheries Service, Office of Protected Resources). Maryland, USA: NOAA's National Marine Fisheries Service.

Nalesso, E. (2014). Distribución espacio-temporal de los tiburones martillo, Sphyrna lewini, alrededor de la Isla del Coco (2005-2013), Pacifico Tropical Oriental. (Tesis de maestría). Centro de Investigación Científica y de Educación Superior de Ensenada, Ensenada, Baja California, México.

Sibaja-Cordero, J. A. (2008). Tendencias espacio-temporales de los avistamientos de fauna marina en los buceos turísticos (Isla del Coco, Costa Rica). Revista Biología Tropical, 56(Supplement 2), 113-132.

Sibaja-Cordero, J. A., \& Cortés, J. (2010). Comparación temporal de la composición y zonación de organismos en el intermareal rocoso del Parque Nacional Isla del Coco, Pacífico de Costa Rica. Revista Biología Tropical, 58(Supplement 4), 1387-1403.
Sibaja-Cordero, J. A., Troncoso, J. S., Benavides-Varela, C., \& Cortés, J. (2012). Distribution of shallow water soft and hard bottom seabeds in the Isla del Coco National Park, Pacific Costa Rica. Revista Biología Tropical, 60(Supplement 3), 53-66.

Springer, S. (1967). Social organization of shark populations. In W. Gilbert, R. Mathewson \& D. Rall (Eds.), Sharks, Skates and Rays (pp. 149-174). Baltimore, USA: John Hopkins University Press.

White, E. R., Myers, M. C., Flemming, J., \&. Baum, J. K. (2015). Shifting elasmobranch community assemblage at Cocos Island-an isolated marine protected area. Conservation Biology, 29(4), 1186-1197.

Zanella, I., \& López-Garro, A. (2015). Abundancia, reproducción y tallas del tiburón martillo Sphyrna lewini (Carcharhiniformes: Sphyrnidae) en la pesca artesanal de Golfo Dulce, Pacífico de Costa Rica. Revista Biología Tropical, 63(Supplement 1), 307-317.

Zanella, I., López-Garro, A., Golfín-Duarte, G., \& Saenz, J. C. (2012). Abundancia, tamaño y estructura poblacional del tiburón punta blanca de arrecife, Triaenodon obesus (Carcharhiniformes: Carcharhinidae), en Bahía Chatham, Parque Nacional Isla del Coco, Costa Rica. Revista Biología Tropical, 60(Supplement 3), 339-346.

Zarate, J. (2010). Edad y crecimiento del tiburón martillo (Sphyrna lewini) (Griffith \& Smith, 1834) en la Costa Sur de Oaxaca, México. (Tesis de maestría). Instituto Politécnico Nacional, Centro Interdisciplinario de Ciencias Marinas, La Paz, Baja California Sur, México. 